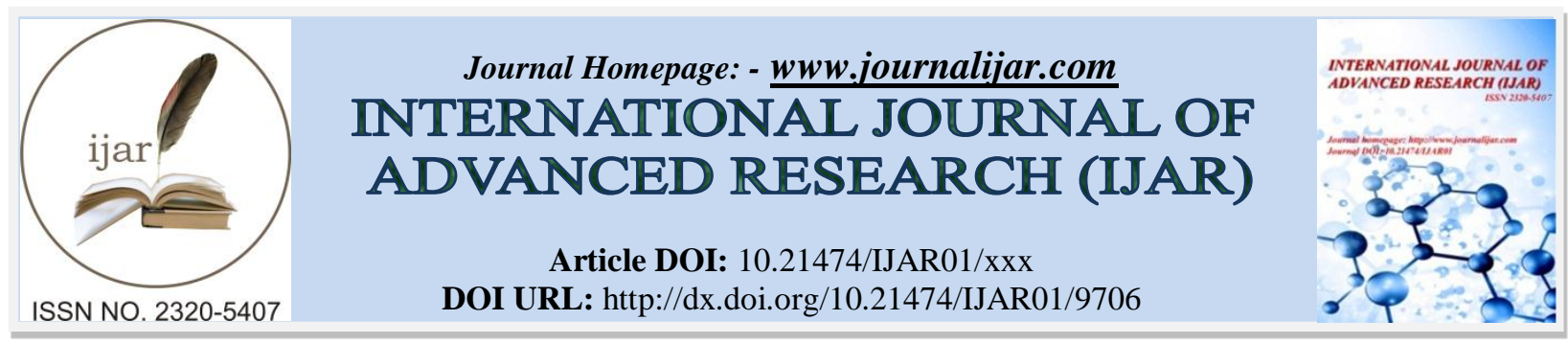

RESEARCH ARTICLE

\title{
EFFECT OF EXTRACTS OF AZADIRACHTA INDICA, KHAYA SENEGALENSIS AND BOSWELLIA DALZIELII ON THE DEVELOPMENT OF THE ANGULAR LEAF SPOT, GROWTH AND DEVELOPMENT PARAMETERS OF RICE (ORYZA SATIVA L).
}

\author{
Serferbe Signaboubo ${ }^{1}$, G. R. Tsopmbeng Noumbo ${ }^{1}$ and Kuiate Jules Roger ${ }^{2}$. \\ 1. Research Unit of Applied Botany, University of Dschang, Box 67 Dschang, Cameroon. \\ 2. Research Unit of Microbiology and Antimicrobial Substances, University of Dschang, Box 67 Dschang, \\ Cameroon.
}

\section{Manuscript Info}

........................

Manuscript History

Received: 08 July 2019

Final Accepted: 10 August 2019

Published: September 2019

Key words:-

Alternaria padwickii, angular leaf spot; rice varieties, growth and development, Chad.

\begin{abstract}
Rice is one of the most widely grown and consumed cereals in Chad. However, its production decreases over the years due to bio-aggressors. This situation pushes farmers to use chemical synthetic plant protection products to remedy insect and disease attacks. These chemicals expose them to risks of poisoning and environmental pollution. To reduce the use of these chemical pesticides, extracts of Azadirachta indica, Khaya senegalensis and Boswellia dalzielii were used to treat rice seeds. These seeds were soaked separately in the different extracts used at a concentration of $50 \mathrm{mg} / \mathrm{ml}$ for one hour before sowing. The incidence and severity of the angular spot, growth and development parameters were assessed. The three types of plant extracts showed a high reduction in the incidence and severity of the disease, and improved certain growth and development parameters. These plant extracts could be used as bio-fungicides in rice cultivation.
\end{abstract}

Copy Right, IJAR, 2019,. All rights reserved.

\section{Introduction:-}

Rice (Oryza sativa L.) is the third most consumed cereal in the world after maize and wheat with a production of 740.9 million tons (FAOSTAT, 2016). It is used in the manufacture of starch, health foods, alcohol and pharmaceuticals (Webster and Gunnell, 1992). In Chad, its production in 2018 was 257,701.23 tons for an area of $182,403,587$ ha or 1.4 t/ha (ONDR, 2018). This yield is low compared to other producing countries such as Burkina Faso (1.9t/ha) and Nigeria (2t/ha) (FAOSTAT, 2017). Among these diseases, those caused by fungi are the most important because they cause severe damage to rice plants and considerably reduce field rice yields compared to viral or bacterial diseases (Habib et al., 2012). Ora et al. (2011) have shown that most fungal diseases are seed-borne to seedlings. The angular leaf spot caused by Alternaria padwickii is responsible for discoloration and seedling meltdown (Naeimi et al., 2003). It considerably reduces photosynthetic activity and therefore disrupts the growth and development of plants in the field (Ou, 1985). Chemical control is generally used to control this disease (Ibian et al., 2006). However, improper handling of chemical fungicides leads to soil microflora degradation, environmental pollution and resistance development in some fungal species (Schillberg et al., 2001; Arcury et al., 2002). On the other hand, plant-extract-based bio-fungicides would be an effective and inexpensive alternative for fungal disease control (Kuri et al., 2011). Herbal fungicides are biodegradable and less toxic (Delvin and Zettel, 1999). The studies

Corresponding Author:-Serferbe Signaboubo.

Address:-Research Unit of Applied Botany, University of Dschang, Box 67 Dschang, Cameroon. 
of Mansur et al. (2013); Nguefack et al. (2013) and Serferbe et al. (2015) have shown that seed treatment (Triticum eastivum, Zea mays, Oryza sp and Gossypium barbadense) with plant extracts result in giving healthy and vigorous seedlings. The work of Khan et al. (1991) showed that Neem leaves and seeds have the ability to prevent the development of fungi. The purpose of this study is to evaluate the antifungal activity of Azadirachta indica, Khaya senegalensis and Boswellia dalzielii extract on the angular spot and their effect on improving rice yield.

\section{Materials and Methods:-}

Seed source and plant material:-

The rice seeds were obtained from the National Rural Development Agency (ANADER) in Bongor, Mayo - Kebbi East province, Chad. Eight (08) rice varieties were collected (TOX, CH3, CH8, WITA9 D6, D4, D3 and D1).

The plant organs (Azadirachta indica fruits, Khaya senegalensis seeds and Boswellia dalzielii bark) were harvested in Pala, Chad.

\section{Preparation of extracts:-}

These harvested plant organs (fruits, seeds and bark) were dried in an oven at a temperature of $45^{\circ} \mathrm{C}$ for 7 days and ground to powder using a SEVEN 7 STAR GERMANY brand grinder. One hundred grams of powder from each plant was macerated separately in $500 \mathrm{ml}$ of distilled water for 48 hours. The mixture was filtered using No. 1 Wattman paper and the resulting filtrate was dried in an oven at a temperature of $45^{\circ} \mathrm{C}$ until the water completely evaporated.

\section{Seed treatment:-}

The seeds of the 8 rice varieties (CH3, CH8, D1, D3, D4, D6, TOX and WITA9) were dipped separately in different extract solutions including Azadirachta indica, Khaya senegalensis and Boswellia dalzielii at a concentration of 50 $\mathrm{mg} / \mathrm{ml}$ for one hour. Distilled water and MANCOZEBE $80 \mathrm{WP}(1 \mathrm{mg} / \mathrm{ml})$ were used as negative and positive controls respectively. The treated seeds were then stored in blotting paper to remove excess moisture from the surface and dry in the open air.

\section{Evaluation of the different extracts:-}

Field trial was conducted at the Institute of Agricultural Research for Development (IRAD) in Dschang ( $5^{\circ} 26 \mathrm{~N}$ and $10^{\circ} 26 \mathrm{~W}$ ) from June to October (2016 and 2017). Eight rice varieties were sown in a Split Plot Device over an area of $609 \mathrm{~m}^{2}$ with three replicates. Each block consisted of eight (8) $13 \mathrm{~m}^{2}$ (13 $\left.\mathrm{m} \mathrm{x} 1 \mathrm{~m}\right)$ elementary plots. The elementary plots formed by five (5) subplots of $2 \mathrm{~m}^{2}$ each. The number of infected tillers in each elementary plot was counted and then examined during the tillering, heading and maturity stage on 10 random plants. The impact was determined by the following formula:

$\mathrm{I}=\frac{\text { Number of infected talles }}{\text { Total number of tillers per poke }} \times 100$

Severity of the angular leaf spot was determined on a scale from 0 to 9 (IRRI, 1996).

For growth parameters, plant size was measured using a graduated ruler from the crown, and the number of leaves per plant and the number of tillers per plant were counted. The leaf area $(\mathrm{cm} 2)$ was determined according to the formula of Winter \& Coll (1956).

\section{$\mathbf{S F}=\mathbf{L} \times \mathbf{W} \times \mathbf{K}$}

(with $\mathrm{K}=0.754, \mathrm{~L}=$ length of the sheet and $1=$ width of the sheet).

With regard to development parameters, the number of panicles per plant and the number of seeds per panicle were recorded and the weights of 1000 seeds $(\mathrm{g})$ were measured using a $0.01 \mathrm{~g}$ Mettler precision balance. The yield (t/ha) of paddy rice seed was calculated according to the formula of Lacharme (2001).

Yield $=\mathrm{NP} / \mathrm{m}^{2} \times \mathrm{NT} / \mathrm{P} \times \mathrm{Npa} / \mathrm{T} \times \mathrm{NG} / \mathrm{Pa} \times \mathrm{PG}$

$\mathrm{NP} / \mathrm{m}^{2}=$ number of plants $/ \mathrm{m}^{2}-\mathrm{NT} / \mathrm{P}=$ number of tillers $/$ foot $-\mathrm{NPa} / \mathrm{T}=$ number of panicle $/$ ball $-\mathrm{NG} / \mathrm{Pa}=$ number of grains/panicles and $\mathrm{PG}=$ weight of a grain. 


\section{Statistical analysis:-}

The data collected were subjected to an analysis of variance (ANOVA) using the SPSS Software version 17 in order to detect significant differences between the averages. The Duncan Test Comparison Test was used to analyze the significance of the results at a probability threshold of $5 \%$.

\section{Results:-}

All rice plants from seeds treated with Azadirachta indica extract, Khaya senegalensis and Boswellia dalzielii and MANCOZEBE had significantly lower incidence $(\mathrm{P} \leq 0.05)$ than those from negative controls (Table 1$)$. The antifungal efficacy of these extracts varied depending on the treatment and phenological phase of the rice. During the tillering stage, plants of variety D6 from seeds treated with Azadirachta indica extract $(50 \mathrm{mg} / \mathrm{ml})$ showed the lowest incidence $(0.1 \%)$. In contrast, the incidence of angular spot in negative control plants was significantly high $(9.11 \%)$. The incidence of angular spot of CH8 variety plants whose seeds have been treated with Boswellia dalzielii extract was $0.6 \%$ compared to $9.11 \%$ for negative control plants of the same variety. Treatment with Khaya sengalensis extract resulted in an incidence of $0.17 \%$ in the TOX variety compared to $8.5 \%$ for control plants. During the heading stage, the TOX, WITA9 and D4 varieties treated with Azadirachta indica extract showed low incidences of $0.15 \%, 0.78 \%$ and $1.51 \%$ respectively, while they were high at $17.68 \%, 13.92 \%$ and $6.11 \%$ for negative control plants. The same is true for the incidence of the angular spot on rice plants treated with Boswellia dalzielii extract, which were $0.29 \%$ (TOX), $0.37 \%$ (D6), $0.75 \%$ (WITA9), and $0.6 \%$ (CH8), lower than those of negative control plants. The extract of Khaya senegalensis recorded a low incidence of $2.37 \%$ compared to $12.1 \%$ for negative control plants and $3.17 \%$ for positive control plants. No angular spot manifestations were observed in variety D3. During the maturity stage, the incidence of the angular spot on plants of the CH8 variety treated with Azadirachta indica, Boswellia dalzielli and Khaya senegalensis extract was $14.83 \%, 10.75 \%$ and 14.8 $\%$ respectively, while that of negative control plants reached $100 \%$.

Table 1:-Variation in the incidence of the angular spot of rice according to treatments with of extracts Azadirachta indica Khaya senegalensis and Boswellia dalzielii

\begin{tabular}{|c|c|c|c|c|c|c|c|c|c|}
\hline \multirow{2}{*}{$\begin{array}{l}\text { Treatment } \\
\text { at } 50 \mathrm{mg} / \mathrm{ml}\end{array}$} & TOX & D6 & CH3 & D1 & WITA9 & D4 & CH8 & D3 & Mean \\
\hline & \multicolumn{9}{|c|}{ Tillering phase } \\
\hline A. indica & $0,11 \mathrm{~b}$ & $0,1 \mathrm{~d}$ & $0,8 \mathrm{~d}$ & $0,5 \mathrm{~d}$ & $0,13 d$ & $0,78 \mathrm{e}$ & $4,44 b$ & - & $0,84 \pm 1,4 \mathrm{~b}$ \\
\hline B. dalzielii & $0,29 \mathrm{~b}$ & $0,37 \mathrm{~cd}$ & $1,67 \mathrm{c}$ & $1,75 \mathrm{~cd}$ & $0,75 \mathrm{~cd}$ & $1,83 \mathrm{cde}$ & $0,6 \mathrm{~d}$ & - & $0,91 \pm 0,73 b$ \\
\hline K. senegalensis & $0,17 \mathrm{~b}$ & $0,26 \mathrm{~d}$ & $2,68 b$ & $4,53 b c$ & $9,53 \mathrm{ab}$ & $3,89 \mathrm{bc}$ & $4,44 b$ & - & $3,18 \pm 3,2 b$ \\
\hline Positive control & $0,1 \mathrm{~b}$ & $1,08 \mathrm{~b}$ & $0,05 \mathrm{~d}$ & $1,17 \mathrm{~d}$ & $0,11 \mathrm{~d}$ & $0,09 \mathrm{f}$ & $1,43 c$ & - & $0,5 \pm 0,6 b$ \\
\hline \multirow[t]{2}{*}{ Negative control } & $8,5 \mathrm{a}$ & $9,11 \mathrm{a}$ & $3 a$ & $10,35 a$ & $10,35 a$ & $6,05 a$ & $62,5 a$ & - & $13,73 \pm 20,04 a$ \\
\hline & \multicolumn{9}{|c|}{ Heading phase } \\
\hline A. indica & $0,15 c$ & $3,26 b c$ & $5,33 b c$ & $0,78 \mathrm{~d}$ & $0,78 \mathrm{c}$ & $1,51 \mathrm{e}$ & $12,5 b c$ & $2,05 \mathrm{~b}$ & $3,29 \pm 4,07 \mathrm{~b}$ \\
\hline B. dalzielii & $1,67 \mathrm{~b}$ & $0,83 \mathrm{~d}$ & $5,33 \mathrm{abc}$ & $5,5 \mathrm{~b}$ & $5,5 b c$ & $4,23 b c$ & $7,58 \mathrm{cde}$ & $0,33 \mathrm{~d}$ & $3,87 \pm 2,6 \mathrm{~b}$ \\
\hline K. senegalensis & $6,67 \mathrm{~b}$ & $2,37 \mathrm{~cd}$ & $9,61 \mathrm{ab}$ & $4,64 b c$ & $11,64 a$ & $4,16 \mathrm{c}$ & $13,5 b$ & $2,5 b c$ & $6,88 \pm 4,24 b$ \\
\hline Positive control & $0,02 \mathrm{c}$ & $3,17 \mathrm{bc}$ & $0,09 \mathrm{c}$ & $5,9 \mathrm{~b}$ & $5,9 \mathrm{bc}$ & $1,9 \mathrm{de}$ & $3,48 \mathrm{de}$ & $1,66 \mathrm{bcd}$ & $2,7 \pm 2,28 b$ \\
\hline \multirow[t]{2}{*}{ Negative control } & $17,68 \mathrm{a}$ & $12,1 \mathrm{a}$ & $7,02 \mathrm{a}$ & $13,92 a$ & $13,92 b$ & $6,11 \mathrm{a}$ & $79,16 a$ & $3,27 \mathrm{a}$ & $19,14 \pm 2,71 \mathrm{a}$ \\
\hline & \multicolumn{9}{|c|}{ Maturity phase } \\
\hline A. indica & $2,3 \mathrm{de}$ & $5,59 \mathrm{bc}$ & $6 b c$ & $3,51 \mathrm{c}$ & $3,51 \mathrm{f}$ & $2,32 \mathrm{ef}$ & $14,83 \mathrm{~cd}$ & $2,3 \mathrm{bcd}$ & $5,04 \pm 4,2 b$ \\
\hline B. dalzielii & $6,3 \mathrm{~cd}$ & $2,66 \mathrm{~d}$ & $7,66 \mathrm{~b}$ & $9,23 b$ & $9,23 \mathrm{bcd}$ & $5,08 \mathrm{bcd}$ & $10,75 d$ & $3,16 b$ & $6,75 \pm 2,9 b$ \\
\hline K. senegalensis & $13,6 \mathrm{bc}$ & $5,22 b c$ & $11,67 \mathrm{~cd}$ & $9,08 b$ & $12,66 b c$ & 4,5 bcde & $14,8 \mathrm{~cd}$ & $2,5 \mathrm{bcd}$ & $9,25 \pm 4,6 b$ \\
\hline Positive control & $0,7 \mathrm{f}$ & $4,37 \mathrm{c}$ & $0,1 \mathrm{~d}$ & $9,19 b$ & 9,19cde & $1,9 \mathrm{fg}$ & $19,66 \mathrm{~b}$ & $2,16 \mathrm{cde}$ & $5,9 \pm 0,5 b$ \\
\hline Negative control & $27,02 \mathrm{a}$ & $13,96 a$ & $11 \mathrm{a}$ & $14,11 \mathrm{a}$ & $16,11 \mathrm{a}$ & $8,33 a$ & $100 \mathrm{a}$ & $5,16 a$ & $24,46 \pm 3,19 a$ \\
\hline
\end{tabular}

Two results read (phenological phase) in the same column are significantly different if they are not followed by the same letters according to Duncan's test $(\mathrm{P} \leq 0.05)$.

Seed treatment of different rice varieties with extracts of Azadirachta indica, Khaya senegalensis, Boswellia dalzielii revealed that the severity of the angular spot was significantly lower than that of negative control plants (Table 2). The antifungal efficacy of these extracts varied according to the treatments and the phenological stage (tillering, heading and maturity). During the tillering phase, the average severity of the angular spot ranged from 0.04 to 2.04. It was significantly lower for plants whose seeds were treated with extracts of Azadirachta indica, Boswellia dalzielii, Khaya senegalensis and mancozebe. Indeed, the TOX variety treated with Azadirachta indica, Khaya senegalensis and Boswellia dalzielii extract had a low severity of $0.09,0.04$ and 0.12 respectively. On the other 
hand, the positive control (mancozebe) had a severity of 0.001 and the negative control had a severity of 1.33. During the heading phase, the effect of Azadirachta indica, Khaya senegalensis and Boswellia dalzielii extract was illustrated by a weak severity of the angular spot. The average severity of the angular spot ranged from 0.83 to 4.01 . Indeed, the variety WITA9 revealed a severity of 1.32 for treatments with Azadirachta indica extracts, 1.08 for treatments with Khaya senegalensis extracts, 1.5 for treatments with Boswellia dalzielii extracts, 0.92 for mancozeb, and 4.12 for the negative control. During the maturity phase, the lowest severity (1) was recorded for the TOX variety whose seeds were treated with Azadirachta indica extract and the mancozeb positive control (0.22) compared to 5 for the angular spot severity in negative controls.

Table 2:-Variation in the severity of the angular spot of rice according to treatments with extracts of Azadirachta indica, Khaya senegalensis and Boswellia dalzielii

\begin{tabular}{|c|c|c|c|c|c|c|c|c|c|}
\hline \multirow{2}{*}{$\begin{array}{l}\text { Treatment } \\
\text { at } 50 \mathrm{mg} / \mathrm{ml}\end{array}$} & TOX & D6 & WITA9 & D4 & CH8 & D3 & CH3 & D1 & Mean \\
\hline & \multicolumn{9}{|c|}{ Tillering phase } \\
\hline A. indica & $0,09 \mathrm{~b}$ & $0,009 \mathrm{c}$ & $0,001 \mathrm{~d}$ & $0,24 \mathrm{~cd}$ & $1,5 \mathrm{bc}$ & - & $0,03 \mathrm{~d}$ & $1,07 \mathrm{~b}$ & $0,36 \pm 0,58 b c$ \\
\hline B. dalzielii & $0,04 \mathrm{~b}$ & $0,15 b$ & $0,08 \mathrm{~cd}$ & $1 b c$ & $0,08 \mathrm{e}$ & - & $1,67 \mathrm{c}$ & $0,08 \mathrm{c}$ & $0,38 \pm 0,6 b c$ \\
\hline K. senegalensis & $0,12 \mathrm{~b}$ & $0,03 \mathrm{c}$ & $1,87 \mathrm{bc}$ & $2,01 \mathrm{ab}$ & $1,5 \mathrm{bc}$ & - & $3 b$ & $2,01 \mathrm{~b}$ & $1,3 \pm 1,13 \mathrm{ab}$ \\
\hline Positive control & $0,001 \mathrm{c}$ & $0,23 \mathrm{ab}$ & - & $0,02 \mathrm{e}$ & $0,05 \mathrm{de}$ & - & $0,002 \mathrm{~d}$ & $0,03 \mathrm{~d}$ & $0,04 \pm 0,078 \mathrm{c}$ \\
\hline \multirow[t]{2}{*}{ Negative control } & $1,33 \mathrm{a}$ & $0,33 \mathrm{a}$ & $2,33 a$ & $2,08 \mathrm{a}$ & $3,87 \mathrm{a}$ & - & $4,05 \mathrm{a}$ & $2,33 \mathrm{a}$ & $2,04 \pm 1,47 a$ \\
\hline & \multicolumn{9}{|c|}{ Heading phase } \\
\hline A. indica & $0,6 \mathrm{~d}$ & $1 \mathrm{c}$ & $1,32 \mathrm{bcd}$ & $0,66 \mathrm{c}$ & $2,93 b c$ & $2,16 \mathrm{~b}$ & $1,70 \mathrm{c}$ & $2,32 \mathrm{~cd}$ & $1,58 \pm 0,83 b$ \\
\hline B. dalzielii & $1,67 \mathrm{~b}$ & $0,33 \mathrm{~d}$ & $1,08 \mathrm{cde}$ & $2,04 b c$ & $1,76 \mathrm{~cd}$ & $1,08 \mathrm{bc}$ & $2,28 b$ & $5,08 \mathrm{~b}$ & $1,9 \pm 1,4 b$ \\
\hline K. senegalensis & $0,67 \mathrm{c}$ & $1,06 a b$ & $1,5 b c$ & $3,1 \mathrm{~b}$ & $2,93 b c$ & $0,05 \mathrm{de}$ & $1,07 \mathrm{~cd}$ & $4,5 \mathrm{bc}$ & $1,86 \pm 1,4 \mathrm{~b}$ \\
\hline Positive control & $0,04 \mathrm{~d}$ & $1,01 \mathrm{bc}$ & $0,92 \mathrm{e}$ & $0,75 \mathrm{c}$ & $1,33 \mathrm{~cd}$ & $0,66 \mathrm{~cd}$ & $0,08 \mathrm{~d}$ & $1,92 \mathrm{~d}$ & $0,83 \pm 0,62 b$ \\
\hline \multirow[t]{2}{*}{ Negative control } & $2,36 a$ & $2 a$ & $4,12 \mathrm{a}$ & $3,5 \mathrm{a}$ & $4,17 \mathrm{a}$ & $3,57 \mathrm{a}$ & $5,03 a$ & $7,33 a$ & $4,01 \pm 1,6 a$ \\
\hline & \multicolumn{9}{|c|}{ Maturity phase } \\
\hline A. indica & $1 \mathrm{~d}$ & $1,89 \mathrm{~cd}$ & $1,42 \mathrm{de}$ & $1,25 \mathrm{c}$ & $3,5 \mathrm{def}$ & $4,5 b$ & $3,09 b$ & $2,24 \mathrm{c}$ & $2,36 \pm 1,23 b c$ \\
\hline B. dalzielii & $2,67 b$ & $1,76 \mathrm{cde}$ & $3,26 \mathrm{bc}$ & $1,83 b c$ & $4,15 \mathrm{cde}$ & $1,25 \mathrm{~cd}$ & $2,9 \mathrm{bc}$ & $5,6 \mathrm{a}$ & $2,9 \pm 1,42 b$ \\
\hline K. senegalensis & $1,75 \mathrm{c}$ & $2 b$ & $3,2 b c$ & $2,35 b$ & $6,5 b c$ & $1,9 \mathrm{~d}$ & $2,82 \mathrm{bcd}$ & $3,2 b$ & $2,96 \pm 1,5 b$ \\
\hline Positive control & $0,22 \mathrm{e}$ & $1,5 \mathrm{de}$ & $1,56 \mathrm{de}$ & $1,5 \mathrm{~d}$ & $2,17 \mathrm{fg}$ & $1,16 \mathrm{e}$ & $1,7 \mathrm{de}$ & $1,56 \mathrm{~d}$ & $1,42 \pm 0,56 \mathrm{c}$ \\
\hline Negative control & $5 \mathrm{a}$ & $3,18 \mathrm{a}$ & $5,08 \mathrm{a}$ & $5,48 \mathrm{a}$ & $8,27 \mathrm{a}$ & $4,84 \mathrm{a}$ & $6,04 \mathrm{a}$ & $8,08 \mathrm{a}$ & $5,74 \pm 1,7 \mathrm{a}$ \\
\hline
\end{tabular}

Two results read (phenological phase) in the same column are significantly different if they are not followed by the same letters according to Duncan's test $(\mathrm{P} \leq 0.05)$.

Some growth parameters independent of rice varieties have been significantly improved compared to the negative control (Table 3). The variety WITA09 whose seeds were treated with Azadirachta indica extract had the largest size $(56.05 \mathrm{~cm})$ compared to the negative control rice plants $(48.38 \mathrm{~cm})$. The number of shoots of variety CH8 was significantly higher (36.88) for plants whose seeds were treated with Boswellia dalzielii extract compared to the negative control (30.66). Rice plants of variety D6 whose seeds were treated with Khaya sengalensis extract had significantly higher leaf counts (8.03) than negative control plants (5.09).

Table 4 shows that treatment with Azadirachta indica extract of the TOX variety resulted in the most significantly high number of panicles (16.12) compared to negative control panicles (11.5). The treatment of variety D3 with Azadirachta indica extract showed a significantly higher number of seeds per panicle (142.6) compared to the negative control (118.6). The weight of a thousand seeds of variety D1 whose seeds have been treated with Khaya senegalensis extract is significantly higher $(40.34 \mathrm{~g})$ than that of the negative controls $(19.33 \mathrm{~g})$. The most significantly high yields were obtained with Khaya senegalensis extract treatment in the TOX (5.69 t/ha), CH8 (3.95 $\mathrm{t} / \mathrm{ha})$ and D1 (4.16 t/ha) varieties. Also, variety D6 treated with Boswellia dalzielii extract had a significantly higher yield (4.84 t/ha) compared to the negative control (1.51 t/ha).

Table 3:-Variation in growth parameters of the different rice varieties according to treatments with extracts of Azadirachta indica, Khaya senegalensis and Boswellia dalzielii

\begin{tabular}{|c|c|c|c|c|c|c|c|c|}
\hline $\begin{array}{l}\text { Treatment } \\
\text { at } 50 \mathrm{mg} / \mathrm{ml}\end{array}$ & TOX & WITA9 & CH8 & CH3 & D6 & D4 & D3 & D1 \\
\hline & \multicolumn{8}{|c|}{ Height $(\mathbf{c m})$} \\
\hline A. indica & $45,99 \mathrm{ab}$ & $56,05 a$ & $55,88 \mathrm{bc}$ & $53,55 \mathrm{a}$ & $45,24 a$ & $48,33 a$ & $50,3 \mathrm{abc}$ & $47,16 a$ \\
\hline
\end{tabular}




\begin{tabular}{|l|l|l|l|l|l|l|l|l|}
\hline B. dalzielii & $52,63 \mathrm{a}$ & $52,22 \mathrm{~b}$ & $62,61 \mathrm{a}$ & $45,33 \mathrm{~b}$ & $42,14 \mathrm{a}$ & $45,16 \mathrm{a}$ & $56,05 \mathrm{a}$ & $44,36 \mathrm{ab}$ \\
\hline K. senegalensis & $45,52 \mathrm{ab}$ & $51,16 \mathrm{~b}$ & $56,84 \mathrm{bc}$ & $47,44 \mathrm{ab}$ & $37,75 \mathrm{~b}$ & $49,38 \mathrm{a}$ & $52 \mathrm{ab}$ & $41,22 \mathrm{~b}$ \\
\hline Positive control & $40,81 \mathrm{c}$ & $54,22 \mathrm{a}$ & $55,11 \mathrm{bc}$ & $53,38 \mathrm{a}$ & $37,66 \mathrm{~b}$ & $46,22 \mathrm{a}$ & $47,27 \mathrm{bc}$ & $45,83 \mathrm{ab}$ \\
\hline Negative control & $42,38 \mathrm{~b}$ & $48,38 \mathrm{c}$ & $50 \mathrm{~d}$ & $42,66 \mathrm{c}$ & $38,11 \mathrm{~b}$ & $50,61 \mathrm{a}$ & $46 \mathrm{c}$ & $46,69 \mathrm{a}$ \\
\hline & Number of leafs/plant \\
\hline
\end{tabular}

Two results read in the same column are significantly different if they are not followed by the same letters according to the Duncan Test $(\mathrm{P} \leq 0.05)$.

Table 4:-Variation in the development parameters of the different rice varieties according to the treatments with extracts of Azadirachta indica, Khaya senegalensis and Boswellia dalzielii

\begin{tabular}{|l|l|l|l|l|l|l|l|l|l|}
\hline \multirow{2}{*}{$\begin{array}{l}\text { Treatment } \\
\text { at 50 mg/ml }\end{array}$} & TOX & WITA9 & CH8 & CH3 & D6 & D4 & D3 & D1 \\
\cline { 2 - 9 } & Number of panicles per plant \\
\hline A. indica & $16,12 \mathrm{a}$ & $16,48 \mathrm{ab}$ & $23,7 \mathrm{ab}$ & $22 \mathrm{a}$ & $15,55 \mathrm{a}$ & $16,22 \mathrm{~cd}$ & $21,44 \mathrm{a}$ & $14,5 \mathrm{~b}$ \\
\hline B. dalzielii & $13,4 \mathrm{~cd}$ & $13,7 \mathrm{bc}$ & $24,59 \mathrm{a}$ & $19,44 \mathrm{de}$ & $13,37 \mathrm{c}$ & $17,18 \mathrm{bc}$ & $20,07 \mathrm{ab}$ & $13,11 \mathrm{bc}$ \\
\hline K. senegalensis & $14,74 \mathrm{bc}$ & $13,48 \mathrm{c}$ & $22,19 \mathrm{~b}$ & $21,44 \mathrm{bc}$ & $12,09 \mathrm{~d}$ & $20 \mathrm{a}$ & $16,33 \mathrm{cde}$ & $13,4 \mathrm{bc}$ \\
\hline Positive control & $13,48 \mathrm{~cd}$ & $17,25 \mathrm{a}$ & $23,18 \mathrm{ab}$ & $19,56 \mathrm{~cd}$ & $14,33 \mathrm{~b}$ & $18,07 \mathrm{~b}$ & $16,88 \mathrm{~cd}$ & $15,72 \mathrm{a}$ \\
\hline Negative control & $11,55 \mathrm{de}$ & $13,7 \mathrm{bc}$ & $20,44 \mathrm{c}$ & $21,8 \mathrm{abc}$ & $12,14 \mathrm{~d}$ & $15,77 \mathrm{e}$ & $15,14 \mathrm{e}$ & $12,7 \mathrm{c}$ \\
\hline \multicolumn{7}{|l|}{} \\
\hline A. indica & Number of seeds per panicle \\
\hline B. dalzielii & $118 \mathrm{a}$ & $138,66 \mathrm{~b}$ & $84 \mathrm{def}$ & $120 \mathrm{a}$ & $102,6 \mathrm{a}$ & $75,3 \mathrm{abc}$ & $142,6 \mathrm{a}$ & $109,67 \mathrm{ab}$ \\
\hline K. senegalensis & $110,3 \mathrm{ab}$ & $123,6 \mathrm{~cd}$ & $94,66 \mathrm{bc}$ & $90,67 \mathrm{bc}$ & $95 \mathrm{bc}$ & $85,66 \mathrm{ab}$ & $136 \mathrm{~b}$ & $60,67 \mathrm{~cd}$ \\
\hline Positive control & $105,3 \mathrm{bcd}$ & $105,6 \mathrm{de}$ & $122,3 \mathrm{a}$ & $79 \mathrm{de}$ & $98,33 \mathrm{~b}$ & $52 \mathrm{c}$ & $120,3 \mathrm{~cd}$ & $110,33 \mathrm{a}$ \\
\hline Negative control & $118,3 \mathrm{a}$ & $140,18 \mathrm{a}$ & $90 \mathrm{~cd}$ & $84 \mathrm{cde}$ & $84,33 \mathrm{~d}$ & $96 \mathrm{a}$ & $126 \mathrm{bc}$ & $107 \mathrm{abc}$ \\
\hline & $99 \mathrm{~d}$ & $95,33 \mathrm{ef}$ & $91,66 \mathrm{bcd}$ & $71 \mathrm{f}$ & $95,66 \mathrm{c}$ & $71 \mathrm{bc}$ & $118,6 \mathrm{~d}$ & $68,33 \mathrm{c}$ \\
\hline A. indica & Weight of 1000 seeds $(\mathbf{g})$ & \multicolumn{5}{|l|}{} \\
\hline B. dalzielii & $34,28 \mathrm{ab}$ & $37,57 \mathrm{bc}$ & $30,01 \mathrm{bcd}$ & $27,57 \mathrm{~d}$ & $27,59 \mathrm{~cd}$ & $23,2 \mathrm{bcd}$ & $38,66 \mathrm{a}$ & $31,72 \mathrm{~b}$ \\
\hline K. senegalensis & $32,37 \mathrm{bc}$ & $32,91 \mathrm{~cd}$ & $33,34 \mathrm{bc}$ & $32,9 \mathrm{abc}$ & $30,92 \mathrm{bc}$ & $30,27 \mathrm{~b}$ & $28,6 \mathrm{cde}$ & $30,33 \mathrm{bc}$ \\
\hline Positive control & $35,99 \mathrm{a}$ & $38,57 \mathrm{ab}$ & $39,01 \mathrm{a}$ & $38,56 \mathrm{a}$ & $43,92 \mathrm{a}$ & $39,94 \mathrm{a}$ & $37,66 \mathrm{~b}$ & $40,34 \mathrm{a}$ \\
\hline Negative control & $28,66 \mathrm{c}$ & $39,91 \mathrm{a}$ & $29,68 \mathrm{de}$ & $29,56 \mathrm{~cd}$ & $27,9 \mathrm{~cd}$ & $20,6 \mathrm{~d}$ & $29,6 \mathrm{~cd}$ & $30,33 \mathrm{bc}$ \\
\hline & $26,66 \mathrm{~cd}$ & $17,57 \mathrm{e}$ & $20,68 \mathrm{f}$ & $18,9 \mathrm{e}$ & $17,59 \mathrm{de}$ & $23,2 \mathrm{bcd}$ & $17,66 \mathrm{ef}$ & $19,33 \mathrm{~d}$ \\
\hline
\end{tabular}


Two results read in the same column are significantly different if they are not followed by the same letters according to the Duncan Test $(\mathrm{P} \leq 0.05)$.

\section{Discussion:-}

Treatment of rice seeds with Azadirachta indica, Khaya senegalensis and Boswellia dalzielii extract had a positive effect in improving growth and development parameters. Rice plants whose seeds were treated with extracts of Azadirachta indica, Khaya senegalensis and Boswellia dalzielii showed significantly higher growth parameters and development compared to the controls. This improvement in growth and development parameters was due to the active compounds present in the various extracts of Azadirachta indica, Khaya senegalensis and Boswellia dalzielii such as phytohormones (auxins, cytokinins), flavonoids, terpenoids (Shamshad and Naqvi, 2002; Marinov et al., 2005). These active compounds would affect the cellular metabolism of rice plants and thus promote good growth and development of rice plants. The work of Idu et al. (2014) has shown that the macro-elements (potassium) and trace elements (sodium, calcium, magnesium, iron, zinc and manganese) contained in the extract of Khaya senegalensis grains can contribute to facilitating photosynthesis and regulating water for greater resistance to temperature variations. Neem seeds are very rich in fatty acids (oleic acid, stearic acid, palmitic acid) amounting to about $50 \%$ of the weight of its seed. These substances would act as growth regulators. The work of Alemika \& Oluwole (1991) and Adelakun et al. (2001) showed that Boswellia dalzielii extract contains saponins, tannins, flavonoids, steroids and terpenes. They facilitate growth and resistance to abiotic stresses. The results obtained in this study with the treatments of Boswellia dalzielii and Azadirachta indica extract are similar to those of Hasan et al. (2005). They showed that the extracts of these two plants improve the growth and development of wheat and cotton. Similarly, the work of Faruq et al. (2015) showed that treating rice seed with Azadirachta indica extracts produced plants with higher yields after germination than the control plants.

The treatment of the different rice varieties with extracts of Azadirachta indica, Khaya senegalensis and Boswellia dalzielii and mancozeb resulted in a reduction in the incidence and severity of the angular spot compared to the negative controls. The inhibitory effect of the extracts of these three plants varied from one extract to another and was similar to that of the mancozebe fungicide (positive control). Similar antifungal activity results of Azadirachta indica and Khaya senegalensis extract on fungi (Fusarium moniliforme, Aspergillus flavus, Aspergillus niger,and Botryodiplodia theobromae) have been reported by Nwachukwu and Umechuruba, (2001); Lakshman and Ahir, (2011). Similarly, Mothana et al. (2011) have demonstrated that Boswellia spp. extract had inhibited the growth of plant pathogenic fungi. Inhibition of Alterania padwickii growth is a consequence of the substances contained in the extracts of Azadirachta indica, Khaya senegalensis and Boswellia dalzielii. Also, the work showed that incidence and severity gradually increased with phenological stages. These results corroborates those of Klomp (1977), who showed that disease sensitivity increased with the age of the plants.

\section{Conclusion:-}

Rice seed treatments with extracts of Azadirachta indica, Khaya senegalensis and Boswellia dalzielii have significantly increased rice growth and development parameters. The extracts of the three plants used gave a significant reduction in the incidence and severity of the angular spot.

The use of extracts from these plants in the control of fungal pathogens in rice can reduce the use of environmentally toxic chemicals. These results provide an alternative for chemical control of fungal diseases. They will allow farmers to reorient the phytosanitary treatments of rice seeds by using plants extracts as sources of pesticides.

\section{Conflict of interest:-}

The authors state that there is no conflict of interest.

\section{Authors' contributions:-}

This work was carried out in collaboration with all the authors. The SS author designed the experiment, performed the statistical analysis and wrote the manuscript; GRTN and KJR supervised the work, reviewed the manuscript and made suggestions. All authors have read and approved the final version of the manuscript. 


\section{Refrences:-}

1. Akihisa, T., Tabata, K., Banno N., Tokuda, H., Nishimura, R., Nakamura Y., Kimura Y., Yasukawa, K., Suzuki, T. (2006). Cancer chemopreventive effects and cytotoxic activities of the triterpene acids from the resin of Boswellia carteri. Biology of Pharmacology Bulletin, 29: 1976-1986.

2. Aluko, M.O. (1975). Crop losses caused by the brown leaf spot disease of rice in Nigeria. Plant Disease Reporter, 59: 609-613.

3. ANADER (Agence National pour le Développement Rural). (2018). Base des données de la production céréalière de 2017/2018. Ministère de l'agriculture du Tchad, Ndjamena, Tchad, pp.25.

4. Arcury, T.A., Quandt, S.A., Russell, GB. (2002). Pesticide safety among farmworkers : perceived risk and perceived control as factors reflecting environmental justice. Environmental Health Perspective, 110: 233 -240.

5. Delvin, J.F., Zettel, T. (1999). Eco-agriculture: Initiatives in Eastern and Southern Africa. J. of Plant Mol. Biol., 6(2): 150-152.

6. FAOSTAT. (2016). FAO statistical databases. Available online at htt:/faostat.fao.org/site/342/ default. aspx. Accessed February 2018.

7. FAOSTAT. (2017). FAO statistical databases. Available online at htt://faostat.fao.org/site/342/ default. aspx. Accessed August 2017.

8. Faruq, AN., Amin, M.R., Islam, M.R., Islam, M.T., Alam., M.M. (2015). Evaluation of some selected seed treatments against leaf blast, brown spot and narrow brown leaf spot diseases of hybrid rice. Advance in Agriculture and Biology, 4 (1): 8-15.

9. Habib, A., Javed, N.S., Sahi, T., Waheed, M. (2012). Detection of seed borne mycoflora of different coarse and fine rice varieties and their management through seed treatments. Pakistan Journal Phytopathology, 24(2):133136.

10. Hassan, M.M., Chowdhury, P.P., Shahidul, A.H.B., Alam, MS. (2005). Antifungal Effects of plants extracts on seed-borne Fungi of wheat seed regarding seed germination, seedling health and vigor index. Pakistan Journal of Biological Sciences, 8 (9): 1284-1289.

11. Ibiam, O.F.A., Umechuruba, C.I., Arinze, A.E. (2006). Seed borne fungi associated with seeds of rice (Oryzae sativa L.) in storage and from the field in Ohaozara and Onicha Local Government areas of Ebonyi State. World Journal Biotechnological, 7: 1062-1-72.

12. Idu, M., Erhabor, J.O., Oghale O., Obayagbona, O. (2014). Antimicrobial qualities, phytochemistry and micronutritional content of Khaya senegalensis (Desr.) A. Juss seed oil. The Journal of Phytopharmacology, 3(2): $95-101$.

13. IRRI. (2002). Standard Evaluation System for Rice. Los Banos, Laguna, Philippines, P.O. Box 933, Manilla, Philippines, pp.81.

14. Khan, T.Z., Gill, M.A., Khan, M.G. (2000). Seed-borne fungi of rice from central Punjab and their control. Pakistan Journal of Phytopathology, 12: 12-14.

15. Klomp, A.O. (1977). Early senescence of rice and Drechslera oryzae in the Wangeningen Plodet, Surinam Agricultural Research Reports No. 859, 97 pp. [Cited in Review of Plant Pathology, 59(5): 2184.

16. Kuri, S.K., Islam, R.M., Mondal, U. (2011). Antifungal potentiality of some botanical extracts against important seedborne fungal pathogen associated with brinjal seeds, Solanum melongena L. Journal of Agricultural Technology. 7 (4): 1139-1153.

17. Lacharme, M. (2001). «Fascicule 2 », Le plant de riz : Données morphologiques et cycle de la plante. Mémento Technique de Riziculture, pp.22.

18. Lakshman, P.B., Ahir, R.R. (2011).Evolution of plant extracts and biocontrol agents against leaf spot disease of brinjal. Indian Phytopathology, 64(4):378-380.

19. Mansur, A., Mehbub, H., Kamrul, H., Chandra, K.D. (2013). Efficacy of Different Plant Extract on Reducing Seed Borne Infection and Increasing Germination of Collected Rice Seed Sample. Universal Journal of Plant Science, 1(3): 66-73.

20. Marinov, D., Ribarova, F., Atanassova, M. (2005). Total phenolics and total flavonoids in bulgarian fruits and vegetables. Journal of the University of Chemical Technology and Metallurgy, 40 (3): 255-260.

21. Mothana, R.A.A., Hasson, S.S., Schultze, W., Mowitz, A., Lindequist, U. (2011) Phytochemical composition and in vitro antimicrobial and antioxidant activities of essential oils of three endemic Soqotraen Boswellia species. Food Chemistry, 126: 1149-1154.

22. Nguefack, JG., Ednar, W.J., Lekagne, D.B.F., Fouelefack, R., Fotio, D., Mbo, J., Jan, T. (2013). Effect of plant extracts and an essential oil on the control of brown spot disease, tillering, number of panicles and yield increase in rice. European Journal of Plant Pathology, 137: 871-882. 
23. Nwachukwu, E.O., Umechuruba, C.I. (2001). Antifongal activities of some leaf extracts on seed-borne fungi of African Yam Bean seeds, seed germination and seedling emergence. Journal of Applied Sciences \& Environment Management, 5(1): 29-32.

24. Ora, N., Faruq, A.N., Islam, M.T., Akhtar, N., Rahman, M.M. (2011). Detection and Identification of Seed Borne Pathogens from Some Cultivated Hybrid Rice Varieties in Bangladesh. Middle-East Journal of Scientific Research, 10(4):482-488.

25. Ou, S.H. (1985). Rice Disease. 2nd Ed. Commonwealth Mycological Institute, ISBN, 085: 198-545. 9, Ferry Lane, Kew, Surrey, England. pp.380.

26. Schillberg, S., Zimmerman, S., Zhang, MY., Fischer, R. (2001). Antiboby-based resistance to plant pathogens. Trangender Research, 10: 1-12.

27. Serferbe, S., Tsopmbeng, N.G., Yaouba, A., Djeugap, F.J., Keuete, K.E. (2015). Efficacy of three local plant extracts as seed treatment on the germination, infection and vigour index of two cotton seed varieties from chad. International Journal of Applied Biology and Pharmaceutical Technology, 6 (2): 39-44.

28. Shamshad, S, Naqvi, M. (2002). Plant growth hormones: growth promotors and inhibitors. In: Pesserakli M. (ed.), handbook of plant and crop physiology. Marcel Dekker, New York. pp 645-657. 99.

29. Sidhu, O., Vishal, Kumar, P., Hari, M.B. (2004). Variability in triterpenoids (Nimbin and Salanin) composition of neem among different provenances of India. Ind. crops products, 19: 69-75.

30. Winter, E.J, Coll. (1956). Some methods of measuring leaf area, in : MILTHORPE (<The growth of leaves i> (Proceed. 3 Easter School agric. Sci. Uniu. Nottingham). Bufterworth scient. Publ., London. pp.195-197. 